UDK 81’42:821.111(94=99)-94.09

\title{
INDIGENOUS AUSTRALIAN AUTOBIOGRAPHY AND THE QUESTION OF GENRE: AN ANALYSIS OF SCHOLARLY DISCOURSE
}

\author{
Oliver Haag
}

\begin{abstract}
This article is concerned with the different genre applications to Indigenous Australian autobiographies. Scholarship has not employed a consistent genre designation for this literature. This article identifies the reasons for a particular genre choice in scholarship and draws on interviews with scholars and authors to test their motivation for either adopting or rejecting the term 'autobiography' for Indigenous life narratives.
\end{abstract}

Keywords: Indigenous Australian autobiography; life writing; genre; scholarly discourse

Autobiography ranks among the most frequently employed genres of Indigenous literature (Cooper et al. 11); there are many reasons for this popularity. First and foremost is the proximity between autobiography and history that provides the possibility of re-connecting with the past and re-telling history. Significantly, as John Joseph Healy remarks, nearly all Indigenous writing is permeated with history (82-83). Much of this stems from the authors' desire to re-write Australian history, which is considered to have excluded and/or misrepresented Indigenous experience (Heiss Dhuuluu-Yala 35-36).

However, the autobiography is seen not only as an enticing format for conveying history, but also as a highly problematic category: many scholars suggest that the term autobiography not be applied in the context of Indigenous literature. This article identifies and considers the different forms assigned to Indigenous autobiographies in scholarly discourse. Drawing from a wide-ranging collection of qualitative in-depth interviews, it examines the genre choices made by authors and scholars.

\section{THE CRITIQUE OF THE AUTOBIOGRAPHICAL GENRE}

An autobiography is commonly defined as a text in which the names of the author, narrator, and protagonist are identical (Lejeune 26), thus a written description [graphia] of one person's life [bios] as written by her- or himself [autos]. Moreover, the autobio- 
graphical genre offers immediate opportunities to convey history-a central concern of many Indigenous authors. It thus appears to be an apt classification for referring to Indigenous life narratives, and the term 'autobiography' is indeed often employed in scholarship (e.g., Rowse; Watson 12-17, 21, 38; Brewster Aboriginal Women's Autobiography; Read, Peters-Little, and Haebich; Haag). Usually, these authors understand autobiography as an umbrella term for both self-authored and recorded Indigenous life stories.

However, the term is also fiercely criticized when applied to Indigenous literature. In the scholarly literature on Indigenous Australian autobiography, I detect three major points of contention: i) the concept of individualism (e.g., Cooper 5-8; Hamilton 129; Robertson 49); ii) the contexts of production (e.g., Shaw 76); and less frequently, iii) the element of writing (e.g., Zierott 39).

The main point of contention is the definition of individualism according to which the autobiography presupposes the idea of an individualized person re-considering and reflecting on his or her life through the process of writing-hence, to know oneself through the act of writing (Gusdorf 129; Weintraub xiii). Joan Newman, for example, perceives autobiography as a genre that is tied to such individualism: "[T]here are some paradoxes and conflicts between traditional Aboriginal concepts of identity and those implied by the choice of autobiography, a product of Western, European culture." (68). Other specialists in Indigenous Studies have advanced similar arguments (e.g., Michaels 173; Attwood 305, 307; Rühl 17-19; Jones “Indigenous Life Stories" 209-210). Narogin, for one, identifies the autobiography with solitary individualism, a form of what he calls 'the battler' genre: "It is an individualized story, and the concerns of the Aboriginal community are of secondary importance" (149). Aileen Moreton-Robinson employs more theory when she calls Indigenous autobiographies 'life writings' or 'life herstories', since the Indigenous autobiographical self was not in any sense individualistic, but rather relational, communal, and connected to others through spirituality and place (1).

The element of individualism makes up the bulk of critique; other reasons are mentioned less frequently. For instance, the contexts of production pose a concern to some scholars in their genre designation. After all, collaborations between Indigenous story-tellers and usually non-Indigenous editors and transcribers constitute $38 \%$ of the body of published Indigenous autobiography (Haag 8). Often, scholars have employed special terms to refer to such collaborations. Most often, the terms 'oral history' and 'life history' are used to designate such stories, which are usually recorded before being edited and published. However, the use and meanings of these terms are not always consistent, but differ according to disciplinary focus. For example, some scholars consider life history — in contrast to the autobiography — a story that is written by a person other than the narrator (Angrosino 3; Geiger 336; Rühl 23-24). Yet at other times, life history is defined as the story of an entire life, in contrast to a life story that is regarded as an account of one or more episodes in a whole life (Brettel 224, 227). Bruce Shaw, in contrast, contends that in the context of Indigenous Australia, life history covered both autobiography and biography:

'Life history' is a relatively new term used to cover biographies and autobiographies written by non-Western informants in collaboration 
with anthropologists...[Life histories] emphasise the importance of the teller's sociocultural milieu, they focus on the perspectives of one unique individual, they have a time depth so that a personal history reveals also matters relevant to a region's or group's local history, and they relate that local history from the point of view of the indigenous narrators. (76)

This definition not only suggests that a collaborative autobiography-or life history - is shaped by both narrator and editor, but also that life history is a form of ethnographic method. Thus, as can be see, the different connotations between the respective genre designations can bear considerably different meanings.

The third major area of contention in scholarship is somewhat related to the concerns surrounding collaborative work. It applies to the form of writing that is implicit in autobiography ('graphein'). In the light of the many orally narrated Indigenous autobiographies, the term 'autobiography', the argument runs, is misleading:

From the Indigenous perspective, the most appropriate terms to describe Aboriginal autobiographical accounts appear to be 'life-(hi)story' and 'life writing'. These terms allow for written as well as oral resources and distance themselves from the traditional Western notion of autobiographical narratives. (Zierott 39)

Quite apart from the fact that 'life writing' as a designation for 'oral resources' appears to be oxymoronic, the critique of the application of the term 'autobiography' to Indigenous literature exhibits two broad forms: it is argued, on the one hand, that orality is a firm element of the written stories that, in most instances, are replete with dialogue, as well as with idiomatic expressions of direct speech. On the other hand, many stories are first recorded electronically before being transcribed. Thus, it is felt that the term 'autobiography' does not adequately represent the Indigenous life writings.

As can be seen, the elements of individualism forming a single author-narratorprotagonist, the collaborative processes of production, and the component of the writing form the basic points of critique of assigning the term 'autobiography' to Indigenous literature. Many of these criticisms, particularly regarding individualism, exhibit parallels to critiques of the autobiographical genre in feminist and minority discourses elsewhere (e.g., Blackburn 133-134). In this respect, then, these criticisms are not uniquely 'Australian'.

Furthermore, there are other genres used in the scholarship on Indigenous autobiography. I have identified more than ten different genre designations. Yet, aside from the instances previously described, the employment of 'alternative' terms to autobiography is often ill-defined, with the reasons for the respective genre choices being hardly expounded, if at all.

Anne Brewster, for example, uses 'auto-ethnography', along with other terms, to refer to autobiographies ("Aboriginal life writing and globalisation"). Unfortunately, Brewster does not further elaborate on the deeper meanings attached to this term. In a loose sense, it signifies either an autobiographical ethnography or an ethnography conducted by persons with an 'insider status' (Reed-Danahay 1-9). The term 'history' is also used; particularly in historical research, where Indigenous autobiographies are 
treated as forms of Indigenous and/or oral history (e.g., McGrath 373, 394; van Toorn 2 ). This genre classification reflects a central characteristic of Indigenous modes of history in which the narrator or historian is often part of the history (Ryan 56-57). Interestingly, while many Australian historians use this term to designate Indigenous autobiographies, European specialists in Indigenous autobiography seem to be critical of the application of the term 'history' to this genre (e.g., Rühl; Zierott). Their argument is that autobiography cannot be taken as history, since it is based on subjective and unverifiable memories, and thus does not rely on verifiable factual evidence such as cross-references and source material (Rühl 20). This difference in genre interpretation between European and Australian readers arises mainly because European scholars hardly take the specificities of Indigenous history into account.

\section{AUTOBIOGRAPHY AND THE CHOICE OF GENRE}

It is evident, then, that scholarship on Indigenous autobiography has not deployed a consistent designation for this genre of Indigenous literature. There are differences both in the disciplinary and national backgrounds of particular scholars (i.e., the interpretation of Indigenous autobiographies as historical documents is roundly criticized by European scholars). Although the term 'autobiography' is used by many researchers in the field, others employ alternative terms - most commonly 'history' to highlight the historical dimension of Indigenous autobiographies and 'life history' and/or 'life writing' so as to evade the concepts of an individualized identity and/or to differentiate between single and joint productions.

This plurality of genre assignation can occasionally cause confusion among readers. For example, a German student to whom I spoke after a lecture regarded this complexity of genre assignment as merely a matter of personal preference evinced by individual scholars; and an Indigenous academic confessed to me during a conference dinner that white academics had nothing better to do than grapple with what he considered unimportant questions. While I do not think this question unimportant, I think it worth further scrutinizing the respective genre designations. In this article, I analyse personal interviews that I conducted with Indigenous and non-Indigenous Australian researchers in Indigenous Studies or a closely related field, which also included Indigenous writers. The interviews are part of a broader research project on the production of Indigenous autobiographies that was published in 2008 (Haag). As part of these interviews, all respondents were asked if 'autobiography' is an appropriate term to refer to published Indigenous life narratives, or why they prefer an alternative genre designation. The present article engages with the interviewees' consideration of genre - not discussed in the 2008 publication —and presents direct quotations from a selection of transcripts.

Indigenous writer Anita Heiss does not regard the question of genre as important. To her, genres are yet another constraint on grasping the pith of Indigenous writings, that is, an expression of cultural survival and rewriting of what she terms the white misrepresentations of Australian history: 
I think again it's the labelling; it's about boxing people into certain genres. And quite frankly, it's for academic purposes...And if it is a matter of what genre it is - whether it's theatre, or poetry, or autobiography, or whatever, fiction - all our books have common themes of survival, oppression, the ongoing cultural genocide of one government after the next. It tends to maintain or reclaim identity and language. So it doesn't even matter what genre it's in. (Heiss, Personal interview)

Having published across several different genres, Heiss suggests in her interview that genre is only of relevance to academics and publishers, while the contents of Indigenous literature were basically the same, that is, political and historical re-writing. This reaction is suggestive of the (autobiographical) genre being seen as a site of re-writing and resistance, hence evincing the claim that it disrespects and trespasses genre borders and readers' conventions. From this perspective, genre is not irrelevant, but-precisely because it is being disrespected and trespassed - a crucial element of distancing Indigenous literature from western forms. In this sense, the 'disrespecting' of genre functions as a means of 'literary disobedience' and makes the question of genre (or 'non-genre') a political and hence imperative issue.

In a very similar fashion, Melissa Lucashenko, an Indigenous novelist, does not ponder over genre assignations, although she is clear about classifying her own writing:

I call my books novels. Steam Pigs is semi-autobiographical, but to me there is no question that they are novels. Certainly they are novels with a strong historical flavour. And I think that's true of a lot of social realist books...But I think generally you can assign a genre if that's important. I don't know if it's important to do that or not. To me it's not. But to all the whites in the bookstore, maybe it is. (Lucashenko, Personal interview)

This answer is very similar to that of Heiss, although probably less outright 'radical'. This author also sees her writing as either correcting or establishing history, but nonetheless chooses to write in fiction because fiction allows more literary freedom and flexibility. Similarly to Heiss, this respondent does not take readers' perceptions into account, even though genre is actually a cultural and literary guide that is determined and recognized by both reader and author. Here, too, genre is seen as being imposed by white booksellers, hence a category to be 'disrespected'.

To Ruby Langford Ginibi, probably the most prolific Indigenous author of autobiography, the question of genre is of considerable concern:

They are autobiography [sic] because they are stories and they tell about our lives. But they are also history, too. Because they are memories of place...It is from our personal survival, of the first people of this land. And they can't deny that, because we have a shared history. White Australia has a Black history. I mean, you can't compare now 216 years of colonial history in this country since 1788 and the last carbon dating of my people being on this continent for....and it's not 40,000 years - it was 120,000 
years. Greek and Roman civilizations: 2,000 years. (Langford Ginibi, Personal interview).

This respondent stresses with vigour the historical value of her autobiographies, emphasizing throughout the interview her non-fictional genre choice and-without my having mentioned the word 'novel' - insisting on her books being recognized as 'autobiography' and 'history' yet not 'novel', for they were what she termed the "truth" (Langford Ginibi, Personal interview). In this instance, genre is not 'disrespected', but chosen deliberately. It was the autobiography and not the novel (or any fictional genre) that was regarded as the most appropriate form in which to re-write both Australian and European history.

Jackie Huggins, co-author of her mother's auto/biography, defines her mother's book, Auntie Rita (1994), as biography (and partly autobiography) because it conveys an Indigenous history; at the same time, she criticizes (Mudrooroo) Narogin's critique of the autobiography as a battler genre that presupposes a form of western individualism:

[The autobiography] is not a totally European concept. We had always told stories about our lives, you know. And what's that? I mean that's autobiographical, surely. And we've told stories about other people's lives, that's a story of our folklore, you know, about our great warriors and great people who come over. It's just been recently that that has been transformed into a written literature. And I don't think that anyone has ever had a monopoly on writing people's lives, and knowing about them, or documenting it and putting that down. (Huggins, Personal interview)

To this author, history was important in her choice of genre. Huggins regards her book as conveying the life story and experiences of an individual person, as well as the regional/national history that this personal story reflects, thus as both personal and Australian history. The autobiographical genre was considered a vital means of imparting such history, with the element of individualism not being considered a universal category defining the autobiography.

It becomes evident that the Indigenous authors under study are divided over their genre choice and the importance of assigning Indigenous literature to various genres. The evaluation of the interviews shows that all Indigenous respondents regard history as crucial to the Indigenous autobiography but, at the same time, they are divided over the relation between history and genre: there is one group of respondents that considers genre important, and which took a conscious decision to write in the autobiographical genre. In this instance, the conveying of history was a fundamental decision in shaping their writing as autobiography. The other group regards the question of genre as irrelevant. These authors identify their writing in a more literary sense, yet without considering it of less historical value. However, even though respondents in this group deem genre classification unimportant, genre is regarded as a white imposition, thus either indirectly or directly worthy of 'disobedience'. Thus, here too, the genre is at least indirectly decisive when authors use it to convey (personal) history through a nonconventional (e.g., fictional) form and thus to disrespect given genre boundaries and 'confuse' white academics, booksellers, and/or readers. 
Moreover, in contrast to the concerns raised in scholarship, none of the Indigenous authors I interviewed grapple with the term 'autobiography' as such. None show any desire to substitute it for 'life writing', 'auto-ethnography', or 'life history'. It can therefore be reasoned that the differences within particular life writing genres are not of relevance to Indigenous authors, but that these authors are keen to treat Indigenous autobiographies as either a historical genre, or at least a genre that imparts a strong historical (counter) message. Thus, the differences between the respective life writing genres are not deemed important to those authors who chose to publish in the autobiographical genre.

The interviews with non-Indigenous respondents show a different result. Evidently, as scholars of Indigenous autobiography, they stand on the 'other' side of the mutual process of determining and recognizing genre and thus have different priorities from those of authors. Most interviewees, including those involved in the collaboration/editing of Indigenous autobiographies, consider the 'autobiography' an appropriate classification for Indigenous literature. As historian Peter Read, for one, says:

Autobiographies, I think so, yeah. What else would that be? I mean, obviously, some people were helped more than others to write it. Ruby Langford was, I think, helped a right deal by her editor. And I believe that Sally Morgan was too. And I think you could call them autobiographies. (Read, Personal interview)

Read employs the term 'autobiography' in order to refer to Indigenous life stories, and deems the genre apposite for describing both single and jointly authored books. The reference to the editing process reflects the issue of the co/production processes described in scholarship. Read here sees the autobiography as an adequate 'umbrella' genre to understand the different productions of Indigenous autobiographies, yet draws a line between single and joint productions, on the one hand, and semi/fictional work, on the other hand. As history, fiction to him has a weaker status as a historical source. Thus, reading intentions are important to the classification of genre; or put another way, genre ordains the way an Indigenous autobiography is read and analysed by historians. In this case, it is the fiction/non-fiction divide and not the process of editing and collaboration that exerts an influence on the choice of autobiography as a genre.

Gillian Cowlishaw, co-author and editor of Tex and Nellie Camfoo's autobiography Love against the Law (2000), has this to say:

And autobiography is, well, what else would I call it? I suppose people would call it oral history. I didn't think of it as oral history at all. I thought of it as Nellie and Tex having told me about their lives, so with a very particular intention in Tex' case at least. (Cowlishaw, Personal interview)

For Cowlishaw, neither the collaboration nor her personal impact on the editing of the autobiography disqualified the book as autobiography, because the editor's interpretation was kept to a low level. In the book itself, a few explanations of the story's socio-historical context are included, which, however, are placed in especially detached squares clearly separated from the main text. This respondent is thus aware of the considerable differences between 'autobiography' and 'oral history', in which life narratives 
are rather used as sources for academic history texts. Both genres indicate a completely different content and story. Cowlishaw's choice of genre was thus propelled by the idea of affording a sovereign narration of her Indigenous collaborators.

Jennifer Jones, author of a $\mathrm{PhD}$ thesis on Indigenous women's autobiographies, is one of the few respondents who actually grapple with the term 'autobiography':

It's a choice, I suppose. In my thesis, I called them 'autobiographies' throughout, because I started there, and it was too late to go and change it. But I tend to use the term 'life writing' more now. It is more in use now than 'autobiography' because it's difficult to separate the term 'autobiography' from that idea of a singular, main author writing in a corrective way about their achievements...'Life writing' might accept that it's multiple authors or multiple lives, which is much more in key with an Indigenous project which mingles several authors at different levels. (Jones, Personal interview)

This respondent clearly favours the genre of 'life writing', which she sees as breaking with the western concept of an individualized identity. The genre interpretation of 'life writing' evades a confinement of the Indigenous autobiography to western structures of identity. Her genre choice, which mirrors a literary rather than historical concern, is also central to the understanding of and analytical approach to the conception of identity in Indigenous literature. For Jones, the use of the term 'life writing' makes visible the close relations in the identity of different protagonists and the influences these protagonists exert on the 'autobiographic' self.

Lastly, Linda Westphalen, also author of a doctoral thesis on Indigenous women's autobiographies, opted for the genre of 'life history', as this genre reflected both the concepts of an Indigenous identity and the historical information that stems from Indigenous autobiographies:

I made a conscious decision in my thesis not to call them autobiographies, because I think that suggests that their genesis comes from a European perspective, which I don't think is actually the case. The point of my thesis was that Indigenous life histories have their genealogy in discourse from Dreaming, rather than from European sources....The other reason that I would call them life histories rather than autobiographies is that the women themselves call them histories. (Westphalen, Personal interview)

While not completely negating the European influences on published Indigenous autobiographies, this respondent endeavours to elucidate the stories' strong, yet often erased Indigenous background. Apart from distinct idiomatic styles, Westphalen advances three major arguments indicating that Indigenous autobiographies emanate from the discourse of the Dreaming (see also Westphalen "Deadly Lives" 12-13, 73, 227-228). First, autobiographies have the same underlying intentions as Dreamings: education, connecting people with each other and their lands, and identification with the past (78$84,105)$. Second, just as Dreamings are stories of the creation of landscape, so were the authors (re)creating landscape in a colonized space. Thus, the self-creation, how an author has survived invasion as an Indigenous person, evinced a parallel to creation 
stories (29-31). Third, the process of storytelling could be considered a form of jour$n e y$, thus resembling creation movements (85-88). These journeys could be either real movements, as in the frequent theme of reuniting with the ancestral lands, or virtual movements, in the sense that both reader and author undertake a journey through storytelling (22). Westphalen thus tries to establish continuity between contemporary forms of autobiography and ancient/pre-contact forms of story-telling. The genre choice is in this case a prerequisite for construing what I call a sovereign tradition of Indigenous autobiography.

As has become evident, authors and scholars have different priorities. To scholars, the genre constitutes the first step to further interpreting and analysing an Indigenous text. Depending on the respective genre definition, genre is seen as vital to understanding Indigenous autobiographies as i) either historical or literary texts; ii) self or joint productions; and iii) products of European or Indigenous origin. It is, furthermore, conspicuous that the comments in the interviews do not fully reflect the previously described concerns in published scholarship. None of Australian scholars that I interviewed grappled with the form of writing. The prerequisite of individualism, too, has been far less intensely discussed than is the case in printed scholarship. In contrast, many scholars recognized the relation between production process and genre designation. In this case, genre designation is far from a mere preference for applying a particular genre, but rather signifies the extent of interpretation and thus alteration of the original narrations. However, there seems to be at least broad agreement to treat 'joint productions' equally as autobiography. Thus, while the Australian scholars under study seem to be aware of collaboration, most do not argue for adopting specific genre terms to refer to such collaborative work.

The issue of cultural continuity is also closely connected to genre and was raised in the interviews rather than in printed scholarship. As the interviews suggest, the genre is often perceived as quintessentially European, whereas the Indigenous autobiography as a narrative practice - as opposed to a literary genre - may describe a sovereign tradition, as a few respondents suggest. In fact, a few interviewees (both authors and scholars) are keen to underline that autobiography was not a purely European brainchild. Here, genre designations are deployed as a means to establish an Indigenous tradition of autobiography. Genre, in other words, is a central vehicle for creating continuity. In the interviews, I identify the following major reasons for adopting or rejecting a particular genre denomination for Indigenous autobiography:

- Highlighting historical content

- Highlighting literary content

- Telling the "truth" and rewriting history

- Allowing sovereign narrations of the Indigenous narrator in cases of collaboration

- Differentiating between fiction and non-fiction

- Rendering visible the relationality of Indigenous identity and selfhood

- Establishing/inventing continuity and tradition

- Claiming difference

Thus, overall, how a genre is classified is of extreme relevance to the understanding of Indigenous literature. History, identity, and cultural continuity are all firmly connected 
with autobiography. It is the question of genre that determines the analytical approach to identity and autobiographical/literary selfhood. It is the question of genre that signifies the extent of editorial and analytical intrusion into a text. It is the question of genre that casts light on the historicity of a text. And finally, it is the question of genre that makes possible aspirations to what I am tempted to term 'Indigenous literary nationalism', the invention of a pristine literary tradition.

\section{Austrian Research Center for Transcultural Studies, Vienna, Austria}

\section{WORKS CITED}

Angrosino, Michael. Documents of Interaction: Biography, Autobiography, and Life History in Social Science Perspective. Gainesville: U of Florida P, 1989.

Attwod, Bain. "Portrait of an Aboriginal as an Artist: Sally Morgan and the Construction of Aboriginality". Australian Historical Studies 25.99 (1992): 302-318.

Blackburn, Regina. "In Search of the Black Female Self: African-American Women's Autobiographies and Ethnicity". Women's Autobiography. Essays in Criticism. Ed. Estelle Jelinek. Bloomington: Indiana UP, 1980. 133-148.

Brettel, Caroline. "Blurred Genres and Blended Voices: Life History, Biography, Autobiography, and the Auto/Ethnography of Women's Lives". Auto/Ethnography. Rewriting the Self and the Social. Ed. Deborah Reed-Danahay. Oxford: Berg, 1997. 223-246.

Brewster, Anne. "Aboriginal Life Writing and Globalisation: Doris Pilkington's Follow the RabbitProof Fence". Australian Humanities Review 25. March (2002). 16.07.2010. >http://www. australianhumanitiesreview.org/archive/Issue-March-2002/brewster.html< . Reading Aboriginal Women's Autobiography. South Melbourne: Sydney UP, 1996.

Cooper, Annabel. "Talking About My Place/ My Place. Feminism, Criticism and the Other's Autobiography”. Southern Review 28 (1995): 140-153.

Cooper, Judi et al. To Tell My Story. A Study of Practising Professional Indigenous Writers of Australia. Research Report. Sydney: Australia Council for the Arts, 2000.

Cowlishaw, Gillian. Personal interview. 23 Sep. 2004.

Geiger, Susan. "Women's Life Histories: Method and Content". Signs 11.2 (1986): 334-351.

Gusdorf, Georges. "Conditions and Limits of Autobiography". Autobiography: Essays Theoretical and Critical. Ed. James Olney. Princeton: Princeton UP, 1980. 28-48.

Haag, Oliver. "From the Margins to the Mainstream: Towards a History of PublishedIndigenous Australian Autobiographies and Biographies". Indigenous Biography andAutobiography. Eds. Peter Read, Frances Peters-Little, and Anna Haebich. Canberra: ANU E P, 2008. 5-28.

Hamilton, Paula. "Inventing the Self. Oral History as Autobiography". Hecate 16.1-2 (1990): 128133.

Healy, J.J. “'The True Life in Our History': Aboriginal Literature in Australia”. Antipodes 2.2 (1988): 79-85.

Heiss, Anita. Dhuuluu-Yala. To Talk Straight. Publishing Indigenous Literature. Canberra: Aboriginal Studies P, 2003.

. Personal interview. 12 Aug. 2004.

Huggins, Jackie. Personal interview. 18 Aug. 2004.

Jones, Jennifer. "Indigenous Life Stories". Life Writing 1.2 (2004): 209-218. . Personal interview. 04 Aug. 2004.

Langford, Ruby Ginibi. Personal interview. 18 Sep. 2004.

Lejeune, Philippe. Le pacte autobiographique. 1975. Paris: Seuil, 1996. 
Lucashenko, Melissa. Personal interview. 17 Aug. 2004

McGrath, Ann. "Contested Ground: What is 'Aboriginal History'?" Contested Ground. Australian Aborigines under the British Crown. Ed. Ann McGrath. Sydney: Allen \& Unwin, 1995. 359399.

Michaels, Eric: "Para-Ethnography". Bad Aboriginal Art. Tradition, Media, and Technological Horizons. Ed. Eric Michaels. Minneapolis: U of Minnesota P, 1994. 164-175.

Moreton-Robinson, Aileen. Talkin' Up to the White Woman. Indigenous Women and Feminism. 2000. St Lucia: U of Queensland P, 2002.

Narogin, Mudrooroo. Writing from the Fringe. A Study of Modern Aboriginal Literature. Melbourne: Hyland House, 1990.

Newman, Joan. "Race, Gender and Identity: My Place as Autobiography". Whose Place? A Study of Sally Morgan's My Place. Ed. Delys Bird and Dennis Haskell. Pymble: Angus \& RobertsonHarperCollins, 1992. 66-74.

Read, Peter. Personal interview. 13 Aug. 2004.

Read Peter, Frances Peters-Little, and Anna Haebich, eds. Indigenous Biography and Autobiography. Canberra: ANU E P, 2008.

Reed-Danahay, Deborah. Introduction. Auto/Ethnography. Rewriting the Self and the Social. By ReedDanahay. Oxford: Berg, 1997. 1-17.

Robertson, Jo. "Black Text, White Reader". Whose Place? A Study of Sally Morgan's My Place. Ed. Delys Bird and Dennis Haskell. Pymble: Angus \& Robertson-HarperCollins, 1992. 47-54.

Rowse, Tim. "Indigenous Autobiography in Australia and the United States". Australian Humanities Review 33. August-October (2004). 14.10.2009 >http://www.australianhumanitiesreview.org/ archive/Issue-August-2004/rowse.html<.

Rühl, Christiane. Die autobiographische Literatur australischer Aborigines-Frauen. Eine ethnologische Studie. Frankfurt/Main: Lang, 1997.

Ryan, Lyndall. "Reading Aboriginal Histories". Meanjin 45.1 (1986): 49-57.

Shaw, Bruce. "Writing Aboriginal History for the East Kimberley: Methodology and Themes". Oral History Association of Australia Journal 5 (1982-1983): 75-83.

van Toorn, Penny. "Indigenous Australian Life Writing: Tactics and Transformations". Telling Stories. Indigenous History and Memory in Australia and New Zealand. Eds Bain Attwood and Fiona Magowan. Wellington: Bridget William Books, 2001. 1-20.

Ward, Glenyse. Unna You Fullas. Broome: Magabala, 1991.

Watson, Christine. “'My Own Eyes Witness': Australian Aboriginal Women's

Autobiographical Narratives." PhD thesis, University of Queensland, 2001.

Weintraub, Karl. The Value of the Individual: Self and Circumstance in Autobiography. Chichago: U of Chicago P, 1978.

Westphalen, Linda. "Deadly Lives. Palimpsests in Aboriginal Women's Life-Histories"'. PhD thesis, Flinders University of South Australia, 2002. Personal interview. 09 Aug. 2004.

Zierott, Nadja. Aboriginal Women's Narratives: Reclaiming Identities. Münster: Lit Verlag, 2005. 